\title{
ПРИМУШУВАННЯ ДО ШЛЮБУ: СІМЕЙНО-ПРАВОВИЙ АСПЕКТ
}

Таран О. C.

\section{ВСТУП}

Одним із пріоритетних напрямів розвитку українського законодавства на сучасному етапі $є$ приведення його у відповідність до міжнародних стандартів захисту прав людини. При цьому особливої уваги потребує забезпечення реалізації рівних прав та можливостей жінок і чоловіків, зокрема у сфері сімейних правовідносин. Відповідно до статті 24 Сімейного кодексу України (надалі - СК України) примушування жінки та чоловіка до шлюбу не допускається. Таким чином, принцип добровільності є базовим компонентом сім’ї, на якому грунтується їі становлення та розвиток.

Відповідно до звіту відділу примусових шлюбів Міністерства закордонних справ і у справах Співдружності Націй Великої Британії від 24 травня 2019 року протягом 2018 року у світі зафіксовано 1764 випадки примусових шлюбів. Це на 47\% більше, ніж у попередньому 2017 році (568 випадків $)^{1}$. Статистичні дані щодо України у цьому звіті не відображені, та облік примусових шлюбів у нашій державі не ведеться. Водночас відсутність офіційної інформації щодо примусового укладення шлюбу чи примушування особи до збереження шлюбних відносин не може свідчити, що проявів такого явища в Україні немає.

Наприклад, у 2018 році працівниками поліції Прикарпаття було затримано громадянина Німеччини турецького походження, який нелегально перебував на території України, вдерся до квартири своєї колишньої дівчини та погрожуючи ножем вимагав, щоб вона вийшла за нього заміж ${ }^{2}$. Активні міграційні процеси, у результаті яких в Україну на постійне чи тимчасове проживання прибувають особи інших національностей та релігійних поглядів, свідчать про необхідність створення дієвого механізму захисту принципу добровільності шлюбу та попередження укладення примусових шлюбів.

\footnotetext{
1 The Foreign and Commonwealth Office of the Government of the United_Kingdom. Forced Marriage Unit statistics 2018. URL: https://www.gov.uk/government/statistics/forced-marriageunit-statistics-2018 (дата звернення: 28.02.2020).

2 Приставив ніж до горла: на Прикарпатті затримали нелегала, який примушував українку до одруження. УНІАН : вебсайт. URL: https:/www.unian.ua/society/10188015-pristaviv-ni zh-do-gorla-na-prikarpatti-zatrimali-nelegala-yakiy-primushuvav-ukrajinku-do-odruzhennya-video.html (дата звернення: 28.02.2020).
} 
У цьому контексті окремої уваги потребують положення Конвенції Ради Європи про запобігання насильству стосовно жінок і домашньому насильству та боротьбу з цими явищами 2011 року (надалі Стамбульська конвенція), що на міжнародному рівні закріпили необхідність криміналізації примушування до шлюбу. Хоча Україна не ратифікувала цю Конвенцію, але у 2018 році Кримінальний кодекс України було доповнено статтею $151^{-2}$ «Примушування до шлюбу». Відповідні зміни набули чинності 11 січня 2019 року, однак натепер у Єдиному державному реєстрі судових рішень справ щодо примушування до шлюбу немає.

Необхідність створення дієвого механізму захисту прав людини в Україні, збільшення на 47\% зафіксованих випадків примусових шлюбів у світі, неоднозначне сприйняття у суспільстві криміналізації примушування до шлюбу та інших положень Стамбульської конвенції, відсутність у цій категорії судових справ свідчать про актуальність вивчення примушування до шлюбу у контексті сімейного права України та міжнародних актів, а також перспектив розвитку вітчизняного законодавства у цій сфері.

\section{1. Поняття «примушування до шлюбу» \\ та його правова характеристика}

Добровільність шлюбу як його конститутивна ознака вперше була сформована у Давньому Римі та відображала рішення наречених поєднати свої життя та обов'язок поважати один одного ${ }^{3}$. На території України протягом тривалого часу основною формою укладення шлюбу була домовленість батьків наречених, однак, згода дітей також мала велике значення. Вважалось, що за відсутності згоди наречених батьки не мали права примушувати їх до шлюбу, адже, поважаючи права батьків, слід цінувати й права дітей на шлюб ${ }^{4}$.

Примушування наречених до шлюбу позбавляє їх можливості самостійно здійснювати свій життєвий вибір без дискримінації та інших порушень прав людини. За даними Парламентської асамблеї Ради Свропи, для дівчат та жінок примушування до шлюбу може супроводжуватись ізоляцією від сім'і, позбавленням права на освіту, проблемами у сфері репродуктивного здоров'я, небажаною вагітністю,

\footnotetext{
3 Балко О.О. Згода як конститутивний елемент інституту шлюбу в Давньому Римі та в країнах континентального права. Вісник Запорізького національного університету. Юридичні науки. 2015. № 3. С. 30.

4 Гримич М.В. Звичаєве цивільне право українців XIX - початку XX століття. Київ : Арістей, 2006. с. 335.
} 
рабством та домашнім насильством у різних формах 5 . Таким чином, у разі примушування до шлюбу порушується не лише принцип добровільності шлюбу, але й цілий комплекс базових прав людини, зокрема право на сім'ю, материнство, свободу та особисту недоторканість, повагу до своєї індивідуальності, здобуття освіти.

Натепер принцип добровільності шлюбу закріплений у багатьох міжнародних нормативно-правових актах, зокрема у частині 2 статті 16 Загальної декларації прав людини 1948 року визначено, що шлюб може укладатися тільки у разі вільної і повної згоди сторін, що одружуються. У пункті с) статті 1 Додаткової конвенції ООН про скасування рабства, работоргівлі та інститутів і звичаїв, подібних до рабства, 1956 року, інститутом, подібним до рабства, визнається обіцянка батьків, опікунів, сім’ї чи іншої особи видати заміж доньку або укладення жінкою шлюбу за грошову чи матеріальну винагороду, однією з умов отримання якої є позбавлення iіï права на відмову від реєстрації шлюбу. Незважаючи на це, у багатьох країнах нині триває практика укладення шлюбів за домовленістю (arranged marriage), ініціаторами яких є не наречені, а члени їхніх сімей.

Більш повна характеристика добровільності як необхідної умови укладення шлюбу міститься у статті 1 Конвенції ООН про згоду на взяття шлюбу, шлюбний вік та реєстрацію шлюбу 1962 року, за якою не допускається укладення шлюбу без повної і вільної згоди обох сторін. Згода на шлюб має бути виражена нареченими особисто, відповідно до закону, після належного оголошення, в присутності представника влади, що має право на реєстрацію шлюбу, та у присутності свідків. Таким чином, повна та вільна згода наречених на шлюб підтверджується як уповноваженою державою особою, так і свідками церемонії. Згідно зі статтею 2 цієї Конвенції, не допускається реєстрація шлюбу з особою, що не досягла шлюбного віку, крім випадків, коли компетентний орган в інтересах сторін, що укладають шлюб, дозволяє реєстрацію такого шлюбу як виняток за наявності поважних причин.

Конвенція ООН про ліквідацію всіх форм дискримінації щодо жінок 1979 року визначає порушення права жінки на добровільність шлюбу як форму дискримінації. У зв'язку з цим у статті 16 цієї Конвенції закріплено обов’язок держав-учасників гарантувати право жінок на одруження лише зі своєї вільної і повної згоди. 3 метою

\footnotetext{
5 Parliamentary Assembly of the Council of Europe. Forced marriage in Europe : Resolution 2233 (2018). June, 28. 2018. URL: http://assembly.coe.int/nw/xml/XRef/XrefXML2HTML-en.asp?fileid=25016\&lang=en (дата звернення: 28.02.2020).
} 
попередження укладення та збереження примусових шлюбів із міграційних мотивів або питань громадянства у статті 9 Конвенції ООН про ліквідацію всіх форм дискримінації щодо жінок закріплено принцип рівності прав чоловіків та жінок у сфері громадянства. Зокрема, зміна чоловіком громадянства чи одруження з іноземцем не може бути підставою для автоматичної зміни громадянства дружини. Жінку не можна примушувати прийняти громадянство іншої держави у зв'язку iз реєстрацією шлюбу, позбавити іiі громадянства або закріпити за нею статус особи без громадянства у разі здійснення нею відмови від зміни або прийняття громадянства іншої держави.

Спеціальні правові механізми попередження, захисту та подолання наслідків різних форм дискримінації жінок, зокрема у сфері шлюбносімейних правовідносин, закріплені у Стамбульській конвенції 2011 року. Такими заходами є криміналізація примушування до шлюбу та забезпечення державою права осіб, що постраждали від примусових шлюбів, на анулювання, розірвання або припинення такого шлюбу.

Досліджуючи визначення примушування до шлюбу та його зміст у наведених вище міжнародних актах, слід звернути увагу на те, що добровільність шлюбу визначається, як правило, двома критеріями, а саме вільною та повною згодою на шлюб. Натомість у частині 1 статті 51 Конституції України та статті 24 Сімейного кодексу України закріплено, що шлюб грунтується на вільній згоді жінки та чоловіка. Таким чином, у національному законодавстві використовується лише термін «вільна згода», а міжнародні акти, крім вільної згоди, містять також вимоги щодо повної згоди на шлюб.

У праві інших країн також спостерігається використання різних критеріїв у характеристиці добровільності як умови укладення шлюбу. Наприклад, частина 1 статті 12 Сімейного кодексу Російської Федерації визначає, що для укладення шлюбу необхідна взаємна добровільна згода чоловіка та жінки, а також досягнення ними шлюбного віку. У юридичній доктрині взаємність розглядається як згода кожного із подружжя на укладення шлюбу, а добровільність означає відсутність стороннього впливу, зокрема у вигляді насильства, на волевиявлення чоловіка та жінки щодо вступу у шлюб ${ }^{6}$

Закріплений у міжнародних актах принцип повної згоди на шлюб можна охарактеризувати як безумовну згоду чоловіка і жінки на

\footnotetext{
6 Замрий О.Н., Ильина О.Ю., Туманова Л.В. Взаимное согласие и добрая воля мужчины и женщины как условия заключения и основания расторжения брака: правовые аспекты соотношения когнитивной и волевой функции сознания супругов. Психология и право. 2019. Том. 9. № 4. DOI:10.17759/psylaw.2019090409.
} 
укладення шлюбу, що відображається у їх розумінні, готовності та прийнятті всіх правових наслідків укладення шлюбу, а не лише окремих його аспектів. Зрозуміло, що повнота згоди на шлюб нерозривно пов'язана із вільним волевиявленням подружжя на його укладення.

Дотримуючись класичних положень сімейного права, принцип добровільності шлюбу можна визначити як вільну, інформовану та усвідомлену згоду на шлюб ${ }^{7}$. Частина 1 статті 40 СК України встановлює, що згода особи на укладення шлюбу не вважається вільною, якщо шлюб було зареєстровано в результаті фізичного чи психічного насильства.

Відповідно до статті 1 Закону України «Про запобігання та протидію домашньому насильству» фізичне насильство $є$ формою домашнього насильства, що включає ляпаси, стусани, штовхання, щипання, шмагання, кусання, а також незаконне позбавлення волі, нанесення побоїв, мордування, заподіяння тілесних ушкоджень різного ступеня тяжкості, залишення в небезпеці тощо.

Психологічне насильство охоплює словесні образи, погрози, у тому числі щодо третіх осіб, приниження, переслідування, залякування, інші діяння, спрямовані на обмеження волевиявлення особи, контроль у репродуктивній сфері, якщо такі дії або бездіяльність викликали у постраждалої особи побоювання за свою безпеку.

Водночас, крім фізичного та психологічного насильства, за Законом України «Про запобігання та протидію домашньому насильству» формами насильства $є$ також сексуальне та економічне насильство. Слід звернути увагу на те, що відповідно до статті 40 Сімейного кодексу України сексуальне та економічне насильство не передбачені як підстави визначення шлюбу як такого, що укладений без вільної згоди чоловіка та жінки. Для того, щоб встановити, чи можуть ці форми домашнього насильства детермінувати укладення примусових шлюбів, а також чи є інші фактори, що впливають на добровільність шлюбу, слід охарактеризувати причини укладення примусових шлюбів.

Натепер можна виділити такі основні причини укладення примусових шлюбів:

- економічні, зокрема 3 метою отримання прибутку, набуття у власність земельних ділянок, нерухомого майна або цінних рухомих речей у результаті укладення шлюбу одним із подружжя або членами

\footnotetext{
7 Менджул М.В. Добровільність як визначальна умова дійсності шлюбу. Юридичний бюлетень. Вип. 8. 2018. C.130-136. URL: https://dspace.uzhnu.edu.ua/jspui/handle/lib/25290 (дата звернення: 28.02.2020).
} 
його сім'ї, а також нестача коштів та заробітку для забезпечення рівня життя сім’ї у межах базових соціальних стандартів та примушування до шлюбу одного із членів родини з метою зменшення кількості осіб, що перебувають на утриманні ${ }^{8}$;

- етнічні - укладення шлюбу без згоди наречених або одного із них не вважається порушенням, а є частиною релігійних канонів чи національних традицій країни походження жінки чи чоловіка;

- міграційні - набуття громадянства або права постійного проживання в іншій країні за допомогою укладення шлюбу або страх бути позбавленим громадянства чи стати особою без громадянства у разі відмови від укладення примусового шлюбу;

- соціальні - захист репутації сім'ї, узаконення дошлюбних сексуальних стосунків, згвалтувань за допомогою укладення шлюбу, а також стосунків, що суперечать моральним, культурним, етичним, релігійним цінностям певного суспільства 9

- правові - низький рівень правової свідомості та обізнаності громадян у сфері прав людини, що не дозволяють особі повною мірою усвідомлювати умови укладення шлюбу та за якими критеріями шлюб слід визначати як примусовий;

- дискримінаційні - тиск родичів, однолітків та суспільства на особу щодо необхідності набуття нею статусу заміжньої жінки/одруженого чоловіка.

Виділені основні причини укладення примусових шлюбів дають змогу зробити висновок, що сексуальне насильство та економічне насильство можуть також бути передумовами примушування до шлюбу та безпосередньо впливати на його добровільність. Визначення у Сімейному кодексі України фізичного та психічного насильства як єдиних підстав порушення вільної згоди на укладення шлюбу не відповідає сучасному тлумаченню форм насильства та невиправдано звужує розуміння цього поняття. Тому доцільнішим видається використання у Сімейному кодексі загального терміна «насильство» у характеристиці примушування до шлюбу без конкретизації форми насильства у вигляді психічного, економічного, соціального чи сексуального.

\footnotetext{
8 United Nations Human Rights Council. Child, early and forced marriage, including in humanitarian settings. URL: https://www.ohchr.org/EN/Issues/Women/WRGS/Pages/ ChildMarriage.aspx (дата звернення: 28.02.2020).

9 Kazimirski A., Keogh P., Kumari V., Smith R., Gowland S., Purdon S., Khanum N. Forced Marriage: Prevalence and Service Response. Department of Children, Schools \& Families. 2009. P. 6. URL: http://www.natcen.ac.uk/media/23519/forced-marriage-prevalence-service.pdf (дата звернення: 28.02.2020).
} 
3 метою приведення у відповідність положень Сімейного кодексу України до закріпленого у законодавстві тлумачення поняття «насильство» та його форм слід внести зміни до частини 1 статті 40 СК України та викласти їі у такій редакції: «Згода особи на укладення шлюбу не вважається вільною, якщо шлюб було зареєстровано в результаті насильства».

Велике значення у визначенні примушування до шлюбу має відмежування дефініції примусового шлюбу від суміжних понять. У міжнародних актах, науковій доктрині та судовій практиці використовуються декілька термінів для позначення способів порушення принципу добровільності шлюбу, а саме: примусовий шлюб, шлюб за домовленістю, дитячий шлюб.

Примусовий шлюб зазвичай визначають як шлюб, у якому одна або обидві сторони особисто не надали свою повну та вільну згоду на його укладення. Дитячий або ранній шлюб - це шлюб, у якому хоча б один із подружжя не досяг 18 років. За даними ЮНІСЕФ, щороку близько 15 мільйонів дівчат у світі виходять заміж, не досягнувши повноліття. Кількість дитячих шлюбів щорічно зростає і за прогнозами може досягнути 150 мільйонів осіб у 2030 році ${ }^{10}$. Перше місце натепер у світі за кількістю дитячих шлюбів посідає країна Бангладеш, де $52 \%$ дівчат виходять заміж у 15 років.

Дитячий шлюб традиційно розглядають як різновид примусового шлюбу. Така концепція підтримується Великою Британією і пояснюється тим, що особа, яка не досягла повноліття, не може надати повну та вільну згоду на укладення шлюбу, адже через свій вік ще не може повною мірою усвідомити правові наслідки шлюбу ${ }^{11}$.

Натомість у звіті Спеціального комітету експертів Ради Європи 3 питань ромів та кочівників (CAHROM) за 2018 рік визначено, що основним фактором для характеристики певного шлюбу як примусового є відсутність вільної згоди особи, а не ііі вік. Також статистичні дані підтверджують те, що вік особи не може бути основним критерієм для характеристики укладеного нею шлюбу як примусового. Наприклад, за 2018 рік зафіксовано 312 випадків укладення примусових шлюбів, жертвами яких були 15-річні особи, 262 випадки - 16-17-річні особи,

\footnotetext{
10 Plan International organization. 150 million girls are at risk of child marriage by 2030: time to act now. URL: https://plan-international.org/news/2019-01-10-150-million-girls-are-risk-childmarriage-2030-time-act-now (дата звернення: 28.02.2020).

11 United Nations Human Rights Council. Child, early and forced marriage, including in humanitarian settings. URL: https://www.ohchr.org/EN/Issues/Women/WRGS/Pages/ ChildMarriage.aspx (дата звернення: 28.02.2020).
} 
307 випадків - 18-21-річні особи, 235 випадків - 22-25 років, а також у 45 випадках від примусових шлюбів постраждали 41-річні та старші особи. Отже, немає прямої залежності між віком особи та потенційною можливістю примушування її до вступу в шлюб, адже за віковим критерієм примушування до шлюбу спостерігається як до неповнолітніх, так і стосовно повнолітніх осіб.

Не кожний дитячий шлюб є примусовим шлюбом і не можна однозначно стверджувати про наявність примусу, якщо шлюб укладений особами, що не досягли 18 років. Наприклад, в Україні за частиною 2 статті 23 право на шлюб за рішенням суду може отримати особа, яка досягла 16 років, якщо це відповідає іiї інтересам. Шлюб, укладений у порядку частини 2 статті 23 СК України, не може вважатись примусовим, адже у разі вирішення питання про надання права на шлюб суд встановлює справжні наміри особи та визначає, чи відповідає укладення шлюбу волевиявленню особи. Таким чином, не кожний дитячий шлюб, у якому хоча б один із подружжя не досяг 18 років, є примусовим шлюбом. Винятком є випадки, коли укладення шлюбу здійснюється у результаті насильства або ініціаторами такого шлюбу є не наречені, а їхні батьки чи інші особи.

Отже, примусові шлюби можуть стосуватись як дорослих, так i дітей. Для характеристики певного шлюбу як примусового слід відштовхуватись не від вікових критеріїв, а від їх волевиявлення щодо укладення шлюбу та відносин, які склалися між подружжям.

Поряд із термінами «дитячий шлюб» та «примусовий шлюб» у міжнародній практиці використовується дефініція «шлюб за домовленістю» (arranged marriage). На відміну від примусового шлюбу (forced marriage), у разі укладення шлюбу за домовленістю наречені погоджуються на шлюб, але не обирають партнера особисто. Для укладення таких шлюбів пару дочці або сину обирають батьки залежно від касти, етнічної приналежності, релігії та соціально-економічного становища, а також відсутності дошлюбних відносин між потенційним подружжям ${ }^{12}$. Шлюби за домовленістю відрізняються від примусових шлюбів тим, що обоє наречених погоджуються на те, що не вони самостійно, а їхні батьки визначать особу, з якою вони укладуть шлюб, а у примусових шлюбах відсутня повна та вільна згода одного із подружжя на шлюб. Водночас не має гарантії, що шлюб, який був укладений

12 Sabbe A., El. Boujaddayni K., Temmerman M. Marriage and Migration: Moroccan Women's Views on Partner Choice, Arranged and Forced Marriage in Belgium. Migration \& Integration. 2019. DOI: https://doi.org/10.1007/s12134-018-00646-9. 
за домовленістю, не перетвориться згодом на шлюб із примусу або, навпаки, подружжя, що уклало шлюб за домовленістю, буде мати хороші сімейні взаємини.

Таким чином, можна визначити таке співвідношення шлюбу за домовленістю, примусового шлюбу та дитячого шлюбу: віковий критерій чи статус особи, що була ініціатором укладення шлюбу (подружжя, один із подружжя або їхні батьки чи родичі), не може бути підставою для характеристики шлюбу як примусового. Примушування до шлюбу проявляється у відсутності згоди особи на укладення шлюбу, що може бути зумовлена економічними, міграційними, етнічними, соціальними або іншими критеріями та може стосуватись як дорослого, так і особи, що не досягла повноліття. У зв'язку з цим не кожен дитячий шлюб $\epsilon$ примусовим, адже з 16 років можна отримати право на шлюб у судовому порядку, а також не кожен шлюб, організований батьками, не може згодом набути характеру примусового. Тому відсутність повної та вільної згоди на шлюб є єдиним однозначним критерієм визначення певного шлюбу як примусового.

\section{2. Правові наслідки примушування до шлюбу}

У характеристиці примушування до шлюбу велике значення має встановлення та дотримання співвідношення принципу дія-наслідок, що на практиці відображається у видах та формах юридичної відповідальності за порушення встановлених правил поведінки. У разі примушування до шлюбу важливим фактором є створення дієвих, а не декларативних норм у сфері примушування до шлюбу. Це можливо лише тоді, коли законодавчі норми не просто повторюють правила міжнародних договорів, зокрема Стамбульської конвенції, а вводяться з урахуванням суспільних звичаїв та моральних засад, а також відображають практику діяльності організацій, що надають допомогу жертвам примусових шлюбів. Оскільки в Україні немає офіційної статистики щодо примушування до шлюбу, для визначення критеріїв, які мають відображатись у разі формування у законодавстві правових наслідків примушування до шлюбу, використаємо світову статистику.

Згідно $з$ даними Міністерства закордонних справ i у справах Співдружності Націй Великої Британії, найвищий індекс справ щодо примусових шлюбів у 2018 році за результатами досліджень, проведених у більше як 90 країнах світу, зафіксований у таких державах, як: Пакистан (769 шлюбів), Бангладеш (157 шлюбів), Велика Британія (119 шлюбів), Індія (110 шлюбів), Сомалі (46 шлюбів), Афганістан 
(44 шлюбів), Румунія (43 шлюби), Ірак (35 шлюбів), Марокко (14 шлюбів), Алжир (11 шлюбів), інші країни (176 шлюбів) $)^{13}$.

Примусові шлюби за географічною прив'язкою до місця укладення чи проживання подружжя у сучасних умовах охоплюють різні країни світу. Якщо раніше такі шлюби укладались в основному у країнах, де більшість жителів сповідує іслам, то тепер спостерігається тенденція до зростання кількості таких шлюбів у Свропі. Наприклад, за результатами спеціального дослідження, проведеного в Іспанії за результатами діяльності організацій з допомоги жертвам примусових шлюбів, встановлено, що, як правило, потерпілими є молоді жінки із Північної Африки, меншою мірою роми. Крім того, за період з 2015 по 2019 рік збільшилась кількість громадян Іспанії та осіб, які законно проживають на іiі території як жертв примусових шлюбів ${ }^{14}$.

Більшість міжнародних нормативно-правових актів у сфері попередження примусових шлюбів спрямовані на захист прав жінок (наприклад, Конвенція ООН про ліквідацію всіх форм дискримінації щодо жінок, Конвенція Ради Європи про запобігання насильству стосовно жінок і домашньому насильству та боротьбу з цими явищами тощо), однак за гендерною ознакою спостерігається тенденція до зростання кількості чоловіків, яких примушують до шлюбу. Зокрема, за наведеною статистикою у 75\% (1322 зафіксовані випадки) жертвами примусових шлюбів були жінки, у 17\% (297 випадків) - чоловіки, а у 8\% випадків (145 справ) гендерна приналежність жертв не була встановлена. За даними британської компанії суспільного телерадіомовлення (BBC), щорічно тисячі хлопців в Індії викрадають 3 метою примушування їх до укладення шлюбів, у тому числі за межами країни ${ }^{15}$. Однісю з основних проблем у визначенні індексу примусових шлюбів серед чоловічого населення є небажання чоловіків звертатись за допомогою у спеціальні організації та публічно заявляти про те, що вони вступили у шлюб не за власною згодою.

Випадки примушування до шлюбу можуть бути зафіксовані як у сім'ях із невисоким достатком, так і серед осіб, що займають привілейоване становище у своїх країнах. Так, у 2019 році до Верховного

\footnotetext{
13 The Foreign and Commonwealth Office of the Government of the United_Kingdom. Forced Marriage Unit statistics 2018. URL: https://www.gov.uk/government/statistics/forced-marriageunit-statistics-2018 (дата звернення: 28.02.2020).

14 Villacampa C., Torres N. Prevalence, dynamics and characteristics of forced marriage in Spain. Crime Law Soc Change (2019). DOI: https://doi.org/10.1007/s10611-019-09881-2.

15 В Індії викрадають тисячі хлопців і примушують до шлюбу. BBC: вебсайт. URL: https://www.bbc.com/ukrainian/media-43751608 (дата звернення: 28.02.2020).
} 
суду Великої Британії звернулась принцеса Хая, дружина правителя емірату Дубаю Шейха Мохаммеда Бін Рашида Аль Мактума, із вимогою визнати іiі шлюб примусовим та надати їй захисний ордер із забороною чоловіку безпосередньо або за допомогою третіх осіб контактувати з нею, а також примушувати iї залишити територію Великої Британії та повернутись на батьківщину ${ }^{16}$.

Наведені факти свідчать про те, що проблема порушення принципу добровільності шлюбу $є$ актуальною у всіх країнах світу. Примушування до шлюбу не $є$ регіональним, етнічним чи локальним явищем, а має міжнародний характер. Сучасні законодавчі механізми захисту від примушування до шлюбу національного чи міжнародного права мають ураховувати сучасні тенденції розвитку цього явища, а саме бути оріснтованими не лише на жінок як потенційних жертв примусових шлюбів, але й чоловіків як ймовірних учасників цих відносин.

Особливої уваги при цьому потребує розуміння міграційного процесу як одного із основних чинників зіткнення національних традицій країни-походження та країни-перебування у разі тлумачення та визнання шлюбів примусовими, а також відхід від стереотипів щодо географії країн, у яких порушується принцип добровільності шлюбу та соціального статусу осіб, що його уклали.

Натепер велике значення щодо правових наслідків примусових шлюбів мають 32 та 37 статті Стамбульської конвенції. Стаття 32 Конвенції про запобігання насильству встановлює, що держави-учасниці вживають заходи для забезпечення того, щоб шлюби, укладені під примусом, могли бути оскаржені, анульовані або розірвані без покладення належного фінансового або адміністративного тягаря на жертву. Натомість стаття 37 Конвенції про запобігання насильству передбачає, що учасники конвенції криміналізують умисну поведінку з примушування дорослого чи дитини до вступу в шлюб, а також заманювання дорослого або дитини на територію іншої держави для примушування цієї особи до вступу в шлюб.

Незважаючи на те, що прийняття Стамбульської конвенції відбулось у 2011 році, нині не всі країни-члени СС криміналізували примушування особи до вступу в шлюб. Відповідальність за злочини, пов'язані з примусовим шлюбом, передбачена у праві Бельгії, Болгарії,

\footnotetext{
16 Dubai's Princess Haya battles billionaire ruler husband in UK High Court. The Telegraph: вебсайm. URL: https://www.telegraph.co.uk/news/2019/07/03/dubais-princess-haya-flees-uk-learning-disturbing-facts-return/ (дата звернення: 28.02.2020).
} 
Хорватії, Кіпру, Данії, Німеччини, Іспанії, Люксембургу, Мальти, Португалії, Словенії, Швеції та Великої Британії.

Слід зазначити, що криміналізація в Україні примусових шлюбів шляхом доповнення Кримінального кодексу України статтею $151^{-2}$ «Примушування до шлюбу» неоднозначно сприйнята в українському суспільстві. Визнання примушування до шлюбу злочином спрямоване на адаптацію норм вітчизняного права до міжнародних базових стандартів захисту прав людини та недопущення дискримінації у сфері шлюбно-сімейних відносин.

Водночас натепер у Сдиному державному реєстрі судових рішень відсутні як кримінальні справи щодо примушування до шлюбу, так і справи про визнання недійсним шлюбу, укладеного у результаті насильства, або про стягнення шкоди, завданої примусовим шлюбом. Наведені фактори стають підгрунтям для пропозицій щодо декриміналізації примушування до шлюбу в Україні ${ }^{17}$. Така позиція є досить радикальною та може бути сприйнята світовою спільнотою як крок назад у розвитку українського законодавства у сфері попередження та захисту від примусових шлюбів.

Також слід враховувати те, що лише наявності в законодавстві норми про відповідальність за примусовий шлюб не досить, адже основне завдання держави - забезпечити іiі ефективне застосування на практиці. Наприклад, у 2016 році в Швеції вперше було засуджено до 4 років ув'язнення чоловіка за те, що він вивіз в іншу країну свою дочку та примусив іiї укласти шлюб з незнайомим їй чоловіком ${ }^{18}$.

31 січня 2020 року суд Корони м. Бірмінгем (Велика Британія) визнав винним 55-річного чоловіка та його 43-річну дружину у примушуванні до шлюбу їхньої 18-річної племінниці із громадянином Пакистану. Судом було встановлено, що чоловік протягом тривалого часу жорстоко поводився із племінницею, принижував іiі, а укласти шлюб змушував під прицілом мисливської рушниці. Чоловіку призначили покарання у вигляді семи років позбавлення років, а дружині один рік із відстрочкою виконання на 2 роки ${ }^{19}$.

17 Андрушко А. Щодо доцільності криміналізації примушування до шлюбу. Jurnalul juridic national: teorie şi practică. 2018. № 6 (34). C. 170-173. URL: https://dspace.uzhnu.edu. ua/jspui/handle/lib/23328 (дата звернення: 28.02.2020).

18 Hofverberg E. Sweden: First Sentence for "Forced Marriage" Upheld by Appellate Court. URL: http://www.loc.gov/law/foreign-news/article/sweden-first-sentence-for-forced-marriage-upheld-by-appellate-court/ (дата звернення: 28.02.2020).

19 Aisha K. Gill. Of family dynamics and forced marriage. URL: https://www.gulftoday.ae/ opinion/2020/02/05/of-family-dynamics-and-forced-marriage (дата звернення: 28.02.2020). 
Правові норми щодо кримінальної відповідальності за примушування до шлюбу містяться також в окремих країнах, населення яких сповідує іслам. Так, 5 лютого 2020 року до 2,5 року умовно було засуджено жителя Киргизстану за те, що він силоміць видав заміж свою 16-річну дочку за статтею 178 Кримінального кодексу Киргизстану, що передбачає відповідальність за порушення законодавства про шлюбний вік під час проведення релігійних обрядів, а саме шлюбної церемонії за ісламською традицією нікях. Під час судового розгляду батько дівчини пояснив свої дії тим, що не знав про те, що проведення релігійного шлюбного обряду щодо особи, яка не досягла повноліття, за згодою іiі батьків є злочином. Наведені приклади судових рішень свідчать, що норми про притягнення до кримінальної відповідальності за примушування до шлюбу в багатьох країнах не є декларативними, а мають практичне застосування.

Відсутність в Україні судових справ щодо примушування до шлюбу не означає те, що добровільність шлюбів в Україні завжди дотримується та законодавчі механізми захисту від примусових шлюбів не потрібні. У пункті 51 Національного плану дій з виконання рекомендацій, викладених у заключних зауваженнях Комітету ООН з ліквідації дискримінації щодо жінок до восьмої періодичної доповіді України про виконання Конвенції про ліквідацію всіх форм дискримінації щодо жінок на період до 2021 року, на Міністерство юстиції України та Міністерство соціальної політики України покладено обов'язок з упровадження суворого застосування мінімального шлюбного віку на рівні 18 років. Серед основних заходів, які рекомендовано здійснювати, є проведення моніторингу дотримання мінімального шлюбного віку, посилення інформування про шкідливість ранніх шлюбів та співпраці закладів освіти у сфері запобігання укладенню таких шлюбів. При цьому всі рекомендації стосуються ромських національних меншин та дівчат із вразливих груп.

Крім криміналізації примушування до вступу в шлюб, Стамбульська конвенція у статті 32 передбачає, що держави-учасниці вживають заходи для забезпечення того, щоб шлюби, укладені під примусом, могли бути оскаржені, анульовані або розірвані без покладення належного фінансового або адміністративного тягаря на жертву. Зі змісту статті 40 СК України випливає, що правовим наслідком укладення шлюбу в результаті насильства $є$ визнання судом такого шлюбу недійсним. Водночас стаття 45 Сімейного кодексу передбачає, що недійсний шлюб не $є$ підставою для виникнення в осіб прав та обов'язків подружжя з моменту державної реєстрації шлюбу. 
Проте процес притягнення до кримінальної відповідальності за примушування до шлюбу чи визнання примусового шлюбу недійсним у часових межах може тривати досить довго. Примусові шлюби грунтуються на насильстві та можуть супроводжуватись порушенням цілого комплексу прав людини, тому важливо забезпечити швидкий законодавчий механізм припинення таких протиправних дій щодо особи в українському законодавстві.

Це можна втілити за допомогою надання права особам, яких примушують до укладення шлюбу або продовження подружніх відносин, звертатись до суду із вимогою отримання обмежувального припису. Саме такий механізм рекомендовано у Резолюції Парламентської асамблеї Ради Європи № 2233 (2018), що визначає цивільно-правові заходи як дієві способи попередження та вчасного припинення примушування до шлюбу.

Стаття $350^{-1}$ Цивільного процесуального кодексу України (надалі ЦПК України) передбачає право особи, що постраждала від домашнього насильства або насильства за ознакою статі, у судовому порядку отримати обмежувальний припис щодо кривдника. У разі задоволення заяви особи суд визначає в обмежувальному приписі один чи декілька заходів тимчасового обмеження прав особи, яка вчинила домашнє насильство чи насильство за ознакою статі (стаття $350^{6}$ ЦПК України). Такими обмеженнями $\epsilon$, наприклад, заборона перебування у місці проживання постраждалої особи, заборона особисто і через третіх осіб розшукувати постраждалу особу або заборона наближатися на визначену відстань до місця проживання постраждалої особи.

3 метою гармонізації українського законодавства із нормами міжнародних актів у сфері визначення правових наслідків примушування до шлюбу, врахування сучасних тенденцій розвитку примусових шлюбів та розширення географії їх укладення у результаті міграційних процесів, визнаючи те, що примушування до шлюбу може стосуватись як дорослого, так і дитини та водночас визначаючи пріоритет оперативних способів захисту прав людини у цій сфері, видається за необхідне надати право на отримання обмежувального припису особам, які уклали шлюб у результаті насильства. Відповідні зміни слід внести до глави 13 Цивільного процесуального кодексу України. Зокрема, статтю $350^{-1}$ ЦПК України слід викласти у такій редакції: «Заява про видачу обмежувального припису подається до суду за місцем проживання (перебування) особи, яка постраждала від домашнього насильства, насильства за ознакою статі або від примушування до шлюбу». Також 
у частині 1 статті $350^{-2}$ до переліку заявників, що можуть звертатись із заявою у разі видачі обмежувального припису, слід додати пункт 5) особи, які постраждали від примушування до шлюбу. Внесення відповідних змін дасть змогу удосконалити національне законодавство у сфері захисту від примушування до шлюбу.

\section{ВИСНОВКИ}

Примушування до шлюбу є формою насильства, що посягає на добровільність як конститутивну ознаку шлюбу та супроводжується порушенням цілого комплексу прав людини, зокрема права на освіту, особисту недоторканість, вільний вибір місця проживання.

У сучасних умовах потребує перегляду класичний підхід, за яким примушування до шлюбу може стосуватись виключно жінок або дівчат молодого віку та спостерігається тільки у країнах, населення яких за моральними та релігійними засадами допускає укладення шлюбу з ініціативи родичів чи третіх осіб, а не виключно наречених. Активні міграційні процеси сприяють розширенню географії держав, у яких фіксуються випадки укладення примусових шлюбів, що свідчить про глобальний характер проблеми примушування до шлюбу.

Віковий та гендерний критерії не можуть бути основою для визначення шлюбу як примусового. Лише відсутність повної та вільної згоди на шлюб свідчить про його примусовий характер. У зв'язку з цим не кожний шлюб, зареєстрований із особою, вік якої менший 18 років, слід визначати як примусовий, адже визначальним у цьому разі має бути характер волевиявлення особи на укладення шлюбу, а не ії вік.

3 метою покращення правового регулювання у сфері примушування до шлюбу в Україні потребує уточнення дефініція «примусовий шлюб». Слід усунути звужене розуміння у Сімейному кодексі України виключно психічного та фізичного насильства як підстав укладення примусових шлюбів. Сексуальне та економічне насильство також можуть бути причиною примусових шлюбів, тому у частині 1 статті 40 СК України слід використовувати загальний термін «насильство», а не визначати форму, у якій це насильство може бути здійснене. Крім того, враховуючи міжнародну практику боротьби із примушуванням до шлюбу, ефективним механізмом припинення порушень у цій сфері є отримання постраждалою особою обмежувального припису. 3 метою імплементації міжнародної практики у національне законодавство необхідно розширити перелік заявників у справах про видачу обмежувального припису та закріпити у главі 13 ЦПК України право осіб, які 
постраждали від примушування до шлюбу, також звертатись до суду із відповідною заявою. Це дасть змогу вчасно припинити неправомірні дії у сфері примушування до шлюбу та захистити постраждалу особу.

\section{АНОТАЦІЯ}

Дослідження присвячене проблематиці примушування до шлюбу у сімейно-правовому аспекті. На основі аналізу норм українського законодавства, права Свропейського Союзу та міжнародної судової практики виділено основні причини укладення примусових шлюбів та здійснено їх відмежування від суміжних понять. Обгрунтовується, що примушування до шлюбу може бути детерміноване різними формами насильства. Відповідно, потребують перегляду положення Сімейного кодексу України, за якими примусовий шлюб може бути результатом лише фізичного або психічного насильства.

Порівняльний аналіз статистичних даних щодо примушування до шлюбу у різних країнах світу дав змогу встановити тенденцію до розширення географії укладення примусових шлюбів у сучасних умовах. Крім того, спостерігається відсутність прямої залежності між віком, гендерною приналежністю чи соціальним статусом особи та її потенційною можливістю стати жертвою примусового шлюбу. Виділені характеристики зумовлюють розширення механізмів попередження примусових шлюбів та передбачення нових способів захисту прав їх учасників. Обгрунтовано необхідність надання права на звернення до суду із вимогою про видачу обмежувального припису особі, яка постраждала від примушування до шлюбу. Внесення відповідних змін до глави 13 ЦПК України дасть змогу гармонізувати національне законодавство зі світовими стандартами захисту прав людини у сфері недопущення укладення примусових шлюбів.

\section{ЛITEPATУРА}

1. The Foreign and Commonwealth Office of the Government of the United Kingdom. Forced Marriage Unit statistics 2018. URL: https://www.gov.uk/ government/statistics/forced-marriage-unit-statistics-2018 (дата звернення: 28.02.2020).

2. Приставив ніж до горла: на Прикарпатті затримали нелегала, який примушував українку до одруження. УНIAH: вебсайт. URL: https://www.unian.ua/society/10188015-pristaviv-nizh-do-gorla-naprikarpatti-zatrimali-nelegala-yakiy-primushuvav-ukrajinku-do-odruzhennyavideo.html (дата звернення: 28.02.2020). 
3. Балко О.О. Згода як конститутивний елемент інституту шлюбу в Давньому Римі та в країнах континентального права. Вісник Запорізького національного університету. Юридичні науки. 2015. № 3. С. 27-33.

4. Гримич М.В. Звичаєве цивільне право українців XIX - початку ХХ століття. Київ : Арістей, 2006. С. 335.

5. Parliamentary Assembly of the Council of Europe. Forced marriage in Europe: Resolution 2233 (2018). June, 28. 2018. URL: http://assembly.coe. int/nw/xml/XRef/Xref-XML2HTML-en.asp?fileid=25016\&lang=en ～(дата звернення: 28.02.2020).

6. Замрий О.Н., Ильина О.Ю., Туманова Л.В. Взаимное согласие и добрая воля мужчины и женщины как условия заключения и основания расторжения брака: правовые аспекты соотношения когнитивной и волевой функции сознания супругов. Психология и право. 2019. Том. 9. № 4. DOI:10.17759/psylaw.2019090409.

7. Менджул М.В. Добровільність як визначальна умова дійсності шлюбу. Юридичний бюлетень. Вип. 8. 2018. С. 130-136. URL: https://dspace.uzhnu.edu.ua/jspui/handle/lib/25290 (дата звернення: 28.02.2020).

8. United Nations Human Rights Council. Child, early and forced marriage, including in humanitarian settings. URL: https://www.ohchr.org/ EN/Issues/Women/WRGS/Pages/ChildMarriage.aspx (дата звернення: 28.02.2020).

9. Kazimirski A., Keogh P., Kumari V., Smith R., Gowland S., Purdon S., Khanum N. Forced Marriage: Prevalence and Service Response. Department of Children, Schools \& Families. 2009. 73 p. URL: http://www.natcen.ac.uk/ media/23519/forced-marriage-prevalence-service.pdf (дата звернення: 28.02.2020).

10. Plan International organization. 150 million girls are at risk of child marriage by 2030: time to act now. URL: https://plan-international.org/ news/2019-01-10-150-million-girls-are-risk-child-marriage-2030-time-actnow (дата звернення: 28.02.2020).

11. United Nations Human Rights Council. Child, early and forced marriage, including in humanitarian settings. URL: https://www.ohchr.org/EN/Issues/ Women/WRGS/Pages/ChildMarriage.aspx (дата звернення: 28.02.2020).

12. Sabbe A., El. Boujaddayni K., Temmerman M. Marriage and Migration: Moroccan Women's Views on Partner Choice, Arranged and Forced Marriage in Belgium. Migration \& Integration. 2019. DOI: https://doi.org/10.1007/ s12134-018-00646-9.

13. The Foreign and Commonwealth Office of the Government of the United Kingdom. Forced Marriage Unit statistics 2018. URL: https://www.gov.uk/ government/statistics/forced-marriage-unit-statistics-2018 (дата звернення: 28.02.2020). 
14. Villacampa C., Torres N. Prevalence, dynamics and characteristics of forced marriage in Spain. Crime Law Soc Change. 2019. DOI: https://doi.org/10.1007/s10611-019-09881-2.

15. В Індії викрадають тисячі хлопців і примушують до шлюбу. $B B C$ : вебсайт. URL: https://www.bbc.com/ukrainian/media-43751608 (дата звернення: 28.02.2020).

16. Dubai's Princess Haya battles billionaire ruler husband in UK High Court. The Telegraph: вебсайm. URL: https://www.telegraph.co.uk/ news/2019/07/03/dubais-princess-haya-flees-uk-learning-disturbing-factsreturn/ (дата звернення: 28.02.2020).

17. Андрушко А. Щодо доцільності криміналізації примушування до шлюбу. Jurnalul juridic national: teorie şi practică. 2018. № 6 (34). C. 170-173. URL: https://dspace.uzhnu.edu.ua/jspui/handle/lib/23328 (дата звернення: 28.02.2020).

18. Hofverberg E. Sweden: First Sentence for "Forced Marriage" Upheld by Appellate Court. URL: http:/www.loc.gov/law/foreign-news/article/ sweden-first-sentence-for-forced-marriage-upheld-by-appellate-court/ (дата звернення: 28.02.2020).

19. Aisha K. Gill. Of family dynamics and forced marriage. URL: https:/www.gulftoday.ae/opinion/2020/02/05/of-family-dynamics-and-forcedmarriage (дата звернення: 28.02.2020).

\section{Information about author: \\ Taran O. S., Ph.D.,} Associate Professor of the Department of Administrative and Civil Law Disciplines Precarpathian Faculty (Ivano-Frankivsk) National Academy of Internal Affairs 3, Natsionalnoi hvardii str., Ivano-Frankivsk, Ukraine DOI https://doi.org/10.30525/978-9934-588-43-3/2.21 